\title{
Assessment of Quality of Underground Drinking Water: Very near ( $\leq 20$ meters) and Far $(>50$ meters) from the River
}

\author{
Munal Subedi ${ }^{1 *}$, Mamata Gharti Magar ${ }^{1}$, Gita Shrestha Rajbhandari² \\ ${ }^{1}$ Department of Microbiology, Amrit Campus, TU, Nepal. \\ ${ }^{2}$ Department of Botany, Amrit Campus, Tribhuvan University, Nepal.
}

\begin{abstract}
Water quality information is needed to assess the state of water contamination in a variety of community, including those that rely primarily on unimproved underground sources of drinking water. The study was carried out with an aim to assess the quality of ground water in particular sites of the Kathmandu valley. The ground water samples were collected from shallow well, tube well and deep tube wells located at specific places of the valley. The research was focused on physiochemical and bacteriological analysis of underground water from sites near to Bagmati river ( $\leq 20$ meters) and from sites far from Bagmati river ( $>50$ meters). The sampling sites were scattered from Sinamangal to Minbhavan. Total sample size was 100, with 50 in each stratum. Study processing was done during the period from February 2013 to May 2013. Six physiochemical parameters namely $\mathrm{pH}$, Conductivity, Ammonia level, Chloride level, Nitrite level, Nitrate level and Biological parameters (Coliform and Fecal coliform) of each sample was tested. Based on the research work, it was recorded that the underground water close to river ( $\leq 20$ meters) has comparatively high physiochemical and biological parameter (Fecal Coliform) than underground water that were farther from the river ( $>50$ meters). Fecal Coliform was predominant 58\% (29/50) in water nearer to river rather than in water farther from the river $20 \%$ i.e. (10/50). Similarly, the values of physiochemical and biological parameter increased comparatively with more distance i.e. $\leq 10$ meters from river. The finding indicated that the underground water near to river is more polluted than far from the river.
\end{abstract}

Key words: Bacteriological quality, Biological, drinking water, Fecal Coliform, Ground water, Physiochemical.

*Corresponding Author

Email: munalsubedi@yahoo.com

\section{Introduction}

The unplanned urbanization and industrialization have resulted in excess use of environment, in particular water resources [1]. Groundwater is the only alternative source for safe and reliable drinking water. Groundwater is characterized by low temperature, low redox potential, high carbon dioxide and mineral content, less amount of suspended solids, and lack of microbial contaminants. Water from underground sources such as hand pump, shallow and deep well is often of better quality than surface water or other open water sources if the soil is fine-grained and its bedrocks do not have cracks, crevices, and bedding plants, which permit the free passage of polluted water especially within the metropolitan zones. The most common and widespread risk associated with drinking water is its contamination either directly or indirectly by sewage or other wastes of human and animal origin. Bacterial as well as chemical pollution of water sources may occur and is mostly derived from watershed corrosion and drainage from sewage, swamps, or soil with high humus content or seepage through river. Prolonged discharge of industrial effluents, domestic sewage and solid waste dump cause the ground water to become polluted and create health problems [2]. Due to inadequate amount of distributed drinking water (pipe water) by Kathmandu Upatayka Khane pani Limited (KUKL), many citizens in Kathmandu valley are seeking the alternative way to meet their demand. About $45 \%$ people of the valley depend on underground water for drinking and other domestic purposes [3]. Underground water is one of the alternative sources for drinking water in the valley. However, in many places within the valley, it is suspected that water is non-potable because it is often contaminated with various pathogenic as well as opportunistic microflora and toxic chemical compounds by different means, such as improper disposal of garbage, unmanaged sewer system and polluted river. The ground water pollution in urban areas is mostly due to infiltration of urban storm water, leakage of waste water and septic reservoirs, and improper industrial activities [4]. Thus, ground water very near ( $\leq 20$ meters) to polluted river might be polluted due to seepage of polluted river into the underground water resulting in contamination with different chemicals as well as pathogens. Thus households near $(\leq 20$ meters $)$ to 
river may be more polluted than the households which are far ( $>50$ meters) from the river side. As a result, underground water very near to river serves as the commonest vehicle of transmission of a number of infectious waterborne diseases as well as factor for leaching heavy metals from the river.

Changes in water quality are reflected in its physical, chemical, and biological conditions; and these in turn are influenced by physical and anthropogenic activities [5]. If we are to provide safe water and prevent possible waterborne diseases, assessment of water quality and water use patterns based on environmental, social, economic and cultural characteristics of a given area is essential [6].

Here, we have studied the quality of underground water of Kathmandu valley near the river which is $\leq 20$ meters and far from the river which is $>50$ meters. Further, we assessed the Physiochemical parameters like, $\mathrm{pH}$ values, Conductivity, Turbidity, and Chloride content, Nitrite content, Nitrate content, Ammonia content, of underground water along with the Microbial quality (especially coliforms and fecal coliforms) of underground water obtained from the two strata [7-9].

\section{Methodology}

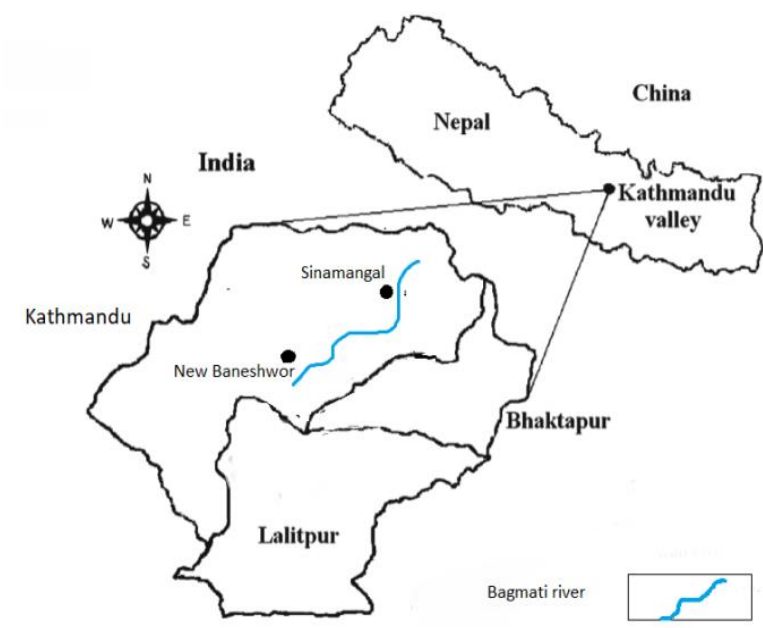

Figure 1: Map of Kathmandu valley showing the study area from Sinamangal to New Baneshwor.

The study was continuously carried out for four months. Locations from Sinamangal to MinBhavan site that included both banks of Bagmati river (Kathmandu) were used.

$300 \mathrm{ml}$ of underground water samples were collected from 100 different households located near site ( $\leq 20$ meters) and far site ( $>50$ meters) from Bagmati river. In order to accomplish the objectives, sample sites have been divided into two strata (near and far).

Stratum 1: 50 samples were taken from the households that were very near the Bagmati river ( $<20$ meters). The sites near the river were chosen assuming that contamination of underground water correlates with proximity from the polluted river that indicates possible seepage of polluted water into the underground water through cracks and crevices.

Stratum 2: In this stratum, 50 samples were selected from those households, which are at least 50 meters far from Bagmati river. It was assumed that a distance of at least 50 meters will avoid intrusion by polluted river water.

One hundred samples i.e. 50 from areas close to river and 50 from areas far from river were tested. During sampling, interview was conducted to know the depth of hand pipe and well, and also to find out the exact number of people who have been using groundwater for drinking as well as other purposes. Samples were collected from Sinamangal to Min-Bhavan from both sides of river. The samples were then transported to a laboratory for analysis. Processing was done on the same day, within 6 hours of collection or preservation at $4^{\circ} \mathrm{C}$ was carried out when an immediate analysis was not possible. Analysis was performed for the determination of different physicochemical parameters and biological parameters of underground water.

The results were compared with standard values recommended by World Health Organization (WHO) for drinking purposes $[7,8]$.

The laboratory analysis of samples was done using standard methods in the laboratory of the Department of microbiology, Amrit Campus [9]. To determine coliforms, Most Probable Number was carried out and was confirmed by using differential media i.e. M-endo agar, and Biochemical Media, Triple Sugar Iron Agar $[8,10]$. Further confirmation was carried by Indole, Methyl Red Voges Proskeur and Citrate utilizations test. Physiochemical parameters of water were tested according to standard protocol (Table 1).

Precautions were taken to prevent any cross contamination during the experiment. The experiments for the biological parameters were performed under aseptic conditions using sterile equipment for sample collection as well as 
processing such as use of sterile bottle for water bottle for collection, disinfection of work table, use pre-purity and post- purity plates for the biochemical test. However, for the physiochemical parameters, fresh, carefully prepared chemicals were used in appropriate amounts.

Table 1: Physiochemical parameters

\begin{tabular}{lll}
\hline S. no & Test parameter & Methods \\
\hline 1 & $\mathrm{pH}$ & pH meter \\
2 & Conductivity & Conductivity meter \\
3 & Chloride $(\mathrm{mg} / \mathrm{l})$ & Iodometric method \\
5 & Ammonia $(\mathrm{mg} / \mathrm{l})$ & Phenate method \\
6 & Nitrate $(\mathrm{mg} / \mathrm{l})$ & Brucine method \\
7 & Nitrite $(\mathrm{mg} / \mathrm{l})$ & UV visible \\
& & Spectrophotometer \\
& & method \\
\hline & & Source (APHA, 1998)
\end{tabular}

\section{Result and Discussion}

Number of households that used underground water for sole drinking purpose was comparatively lower (20\%) in area $\leq 20$ meters distance from river than those in area $>50$ meters distance from river i.e. $60 \%$. However, use of water for other purposes such as cooking and bathing were equal in both distances (Figure 2).

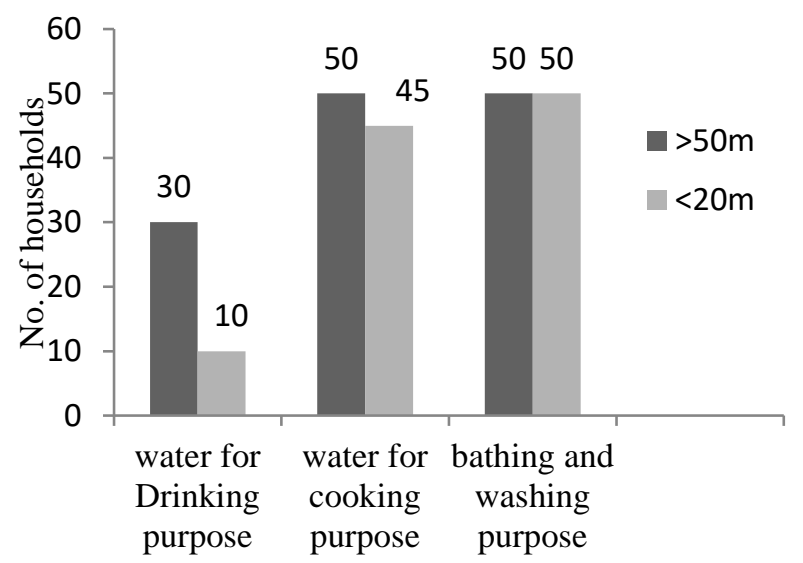

Figure 2: No. of Household that use underground water for different purpose

$76 \%$ (38) of households in areas $\leq 20$ meter distance from the river used conventional sand filter method for the treatment of water while the rest of the households used water without treatment. However, $100 \%$ of the households in area $>50$ meter distance used conventional sand filter method for the treatment of water (Figure 3). Any alteration in water $\mathrm{pH}$ is accompanied by the change in other physiochemical parameters [11]. Our study showed that water was alkaline in most of the samples in areas $\leq 20$ meters and $>10$ meter distance and $\mathrm{pH}$ ranged from 7.2-8.4. However, in areas $\leq 10$ meter distance, $\mathrm{pH}$ ranged from 7.3-8.9, whereas in water samples from areas $>50$ meters distance $\mathrm{pH}$ ranged from 6.9-7.9. $\mathrm{pH}$ value of different studied samples in different distances were within the range prescribed by WHO (6.5-8.5) except in $\leq 10$-meter distance where the upper range was exceeded. High value of $\mathrm{pH}$ may be due to waste discharge and microbial decomposition of organic matter in the water body [12]. Because the distance between the river and the underground water in some cases is less than 10 meters and depth is around 30 feet there might be a possible seepage of river water to the underground drinking water.

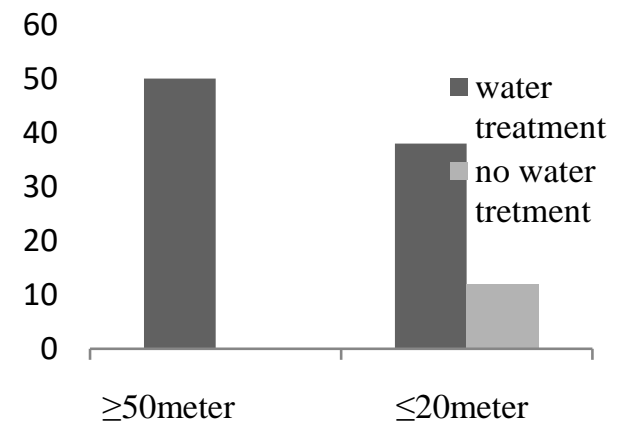

Figure 3: No. of houses using Sand filter as treatment for underground water

Electrical conductivity is one of the tools to assess the purity of water. Often, high electrical conductivity correlates with contamination by anthropogenic sources $[13,14]$. Electrical conductivity was found in the range 764-946 $\mathrm{mho} / \mathrm{cm}$ in the samples from areas $>10$ to $\leq 20$ meter distance. In $\leq 10$ meter distance, it was found in the range of 790-1202 mho/cm, whereas in water sample from areas $>50$ meters distance it was found to be in the range of $658-982 \mathrm{mho} / \mathrm{cm}$. Electrical conductivity was comparatively higher range in $\leq 10$ meters. It is correlated with the presence of salinity of water. One of the reasons for high salinity is the high concentration of cation such as sodium, calcium and magnesium along with chloride, phosphate and nitrate anions [15]. In water sample distance $\leq 10$ meters, the higher range of electrical conductivity may be due to possible leaching of river water in underground drinking water.

The high concentrations of chloride in combination with nitrate or ammonium show that the water is contaminated with domestic sources [16]. Increase in chloride concentration in discharge of municipal 
and industrial waste has been reported [17]. In river Ganga at Vanarasi, Chaudhary and Ojha (1985) found that chloride value ranged from 5.9 to $7.9 \mathrm{mg} / 1$. Chloride was found in the range 14.5-68.2 $\mathrm{mg} / 1$ in samples from areas $>10$ to $\leq 20$ meters $[18,19]$. In $\leq 10$ meter distance, it was found in the range of $39.7-70.2 \mathrm{mg} / 1$ whereas in sample $>50$ meters distance it was found to be $23.9-48.2 \mathrm{mg} / 1$. It is within the desirable limit prescribed by WHO, which is $250 \mathrm{mg} / \mathrm{l}$. According to Versari et al. (2002) chloride concentration higher than $200 \mathrm{mg} / 1$ is considered to be a risk for human health and may cause unpleasant taste of water [19].

Ammonia content in water may be harmful to health since it can be converted to nitrate. If only ammonia is present in the water then, pollution by sewage must be very recent [20]. The occurrence of $\mathrm{NO}_{2}$ with ammonia indicates that sometime has lapsed since the pollution has occurred. If all the nitrogen is present in nitrate form, a long time has been passed after pollution because water has purified itself and all nitrogenous matter has been oxidized [20]. The presence of ammonia in ground water is quite generally a result of natural degradation processes [20]. Ammonia in higher concentration is toxic to man. The toxicity of ammonia increases with $\mathrm{pH}$ because at higher $\mathrm{pH}$ most of the ammonia remains in the gaseous form [21].

Ammonia was found in the range of $0.75-5.5 \mathrm{mg} / 1$ in samples from areas $>10$ meters to $\leq 20$ meters distance. In water from areas $\leq 10$ meters distance, ammonia concentration was higher i.e. in the range $4.2-21.4 \mathrm{mg} / \mathrm{l}$, whereas in water samples from area $>50$ meters distance ammonia concentration was found to be $0.5-10 \mathrm{mg} / 1$. All samples exceeded the WHO guideline for ammonia which is $0.1 \mathrm{mg} / \mathrm{l}$ [6,7]. Although, ammonia pollution is not always due to domestic pollution, high ammonia content in deep well can be due to the underlying intercalated layers of peat and lignite. Ammonia of mineral origin is rare in natural water but its presence is quite generally a result of natural degradation processes most inevitably due to ammonification of organic matter [22].

In present study, Nitrate and Nitrite were found to be in the range of $0.3-3.5 \mathrm{mg} / 1$ and $0.1-2 \mathrm{mg} / \mathrm{l}$, respectively in water samples from areas $>10$ meters and $\leq 20$ meters distance. In samples from $\leq 10$ meters distance, Nitrate and Nitrite concentrations were found to be in the range of 1.4$6.2 \mathrm{mg} / 1$ and 1.6-8.4 mg/l, respectively, whereas in water samples taken from areas $>50$ meters distance these were found to be $0.1-0.8 \mathrm{mg} / 1$ and 0.1-2.1 $\mathrm{mg} / \mathrm{l}$. Although these parameters are comparatively more in water sample $\leq 10$ meter distance, all the values are within the range of WHO. According to $\mathrm{WHO}$, the maximum contaminant levels for nitrates at $50 \mathrm{mg} / 1 \mathrm{NO}^{3-}$ and maximum contaminant level for nitrite is $50 \mathrm{mg} / \mathrm{L}$ $\mathrm{NO}^{3-}$. Also, there have been recorded cases of "blue-baby" syndrome caused by nitrate concentrations only slightly higher than $10 \mathrm{mg} / \mathrm{L}$ NO3- [23]. There is a positive correlation of high nitrate drinking water concentrations to elevated gastric cancer occurrences in Chile and England [24].

The microbiological analysis of water was performed by Most Probable Number. MPN index of analyzed water samples showed wide variation and ranged from 4 to $\geq 2400$ coliforms $/ 100 \mathrm{ml}$. Similarly, MPN index was found in the range from 9 to $\geq 2400$ coliforms $/ 100 \mathrm{ml}$ in samples from $\leq 20$ meters and $>10$ meters distance. In $\leq 10$ meters distance, it was found in the range from 21 to $\geq 2400$, whereas in samples from $>50$ meters distance, it was found to be 4 to $\geq 2400$ coliforms $/ 100 \mathrm{ml}$. This shows that $80 \%(20 / 25)$ of water samples taken from distance $\leq 20$ meters and $\geq 10$ meters is contaminated with coliforms. Similarly, $80 \%(20 / 25)$ of water samples taken from distance $\leq 10$ meters is contaminated with coliforms and $46 \%(23 / 50)$ of water samples from $>50$ meters distance is polluted with coliforms. On analysis of these data, water nearer to river has more coliforms than water farther from the river. The result showed that most of the samples ice. $80 \%(40 / 50)$ water sample nearer from the river $(<20$ meters) has exceeded the WHO standard. Similarly, samples $46 \%(23 / 50)$ water sample far from the river ( $>50$ meters) has exceeded the WHO standard. Several sources of contamination could be suggested and could include the possibility contamination from improper management of sewer system $[6,25]$.

E. coli was found to the predominant organism in total coliforms and in most of contaminated drinking water [25-28]. Likewise, in our study, E. coli was the predominant organism among all 
isolated coliforms. Similarly, fecal coliform was predominant $58 \%(29 / 50)$ in water nearer to river than in water farther from the river $20 \%$ i.e. $(10 / 50)$. Presence of fecal coliform indicates that water is polluted with sewage or from improper management of sewer system [29]. Comparison of coliforms and fecal coliforms in two distances from the river is shown Figure 4.

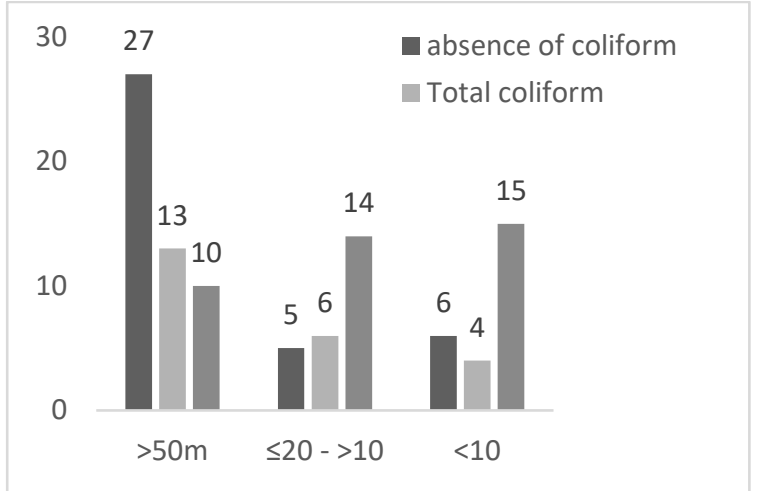

Figure 4: Comparative analysis of Coliform and Fecal Coliform present in underground water $>50$ meters, $\leq 20$ meters and $<10$ meters from the river side.

\section{Limitations of the study}

The study could have been extended further for the isolation and identification of other pathogenic bacteria such as Salmonella Typhi, Vibrio cholerae, Campylobacter jejuni, Helicobacter pylori etc, the presence of which could strengthen the study and confirm the actual presence of the infectious agents in the underground water due to the seepage of the polluted river.

\section{Conclusion}

Present finding indicates that the underground water nearer to river $(\leq 20$ meters $)$ showed comparatively high values of physiochemical and biological parameters than underground water farther (>50 meters) from the river. However, the values of physiochemical and biological parameter increased comparatively if water is taken from even nearer distance i.e. $\leq 10$ meters from river. Some households are using underground water as drinking purpose without or with treatment (sand filter). This might be one of the factors causing water borne diseases as this filter does not assure the reduction of chemical and biological parameter to meet standard value. Thus, water from the underground needs to be treated to reduce the physiochemical parameter and should be disinfected or boiled before consumption to avoid water-borne diseases. It is important to make people who are using underground water i.e. very near to river that the polluted river has consequences to their drinking water sources aware. The government, local agency should raise awareness to the people about the quality of water who are using underground water. Finally, all approaches should be made to make the river water free from chemical and organic pollution.

\section{Conflict of Interest}

None

\section{Authors Contribution}

MS was involved in the study conception and design, data analysis and interpretation. MS and MGM were involved in sample collection, drafting manuscript and correction. GSR was involved in reviewing of the manuscript.

\section{Acknowledgement}

Authors thanks University Grants Commission (UGC), Nepal for providing financial assistance to conduct this research.

\section{References}

1. Singh SP, Pathak D \& Singh R: Hydrobiological studies of two ponds of satna (M.P.) India, Eco.Env.and Cons. 2002 8(3): 289-292.

2. Raja RE, Lydia S, Princy M \& Chritopher G: Physico-Chemical Analysis of Some Groundwater Samples of Kotputli Town Jaipur, Rajasthan. Indian J Environ Prot. 2002 22(2):137-40.

3. MOPPW: Optimizing water use in Kathmandu valley; HMG/Nepal, 2003.

4. Robertson WD, Cherry JA, and Sudicky EA: Ground water contamination from two small septic systems on sand aquifiers 1991 Ground water, 29(1): 82-92.

5. Asian Development Bank and International Centre for Integrated Mountain Development, Kathmandu (ADB/ICIMOD). 2010

6. United Nations: The Millennium Development Goals Report. United Nations Department of Public Information. New York, 2005.

7. World Health Organization (WHO): Guidelines for drinking water quality. 3rd edition, Geneva. 2008.

8. World Health Organization (WHO): Assessing Microbial Safety of Drinking water improving Approaches and Methods. $1^{\text {st }}$ edition, Geneva. 2003.

9. American Public Health Association (APHA): Standard methods for Washington, D.C.1998

10. Aneja KR: Experiments in Microbiology, Plant Pathology and Biotechnology; New Age International, India, 2003. 
11. Wetzel RG: Limology; Saunders Co. Philadelphia, USA, 743;1975.

12. Patil SG, Chonde SG, Jadhav AS \& Raut PD: Impact of Physico-Chemical Characteristics of Shivaji University lakes on Phytoplankton Communities, Kolhapur, India; Research Journal of Recent Sciences. 2012 1(2): 56-60.

13. Pant BR: Ground water in Kathamandu Valley of Nepal; Environ Monit Assess. 2010 178:147-185

14. De Sousa DN, Mozeto AA, Carneiro RL and Fadini PS: Electrical conductivity and emerging contaminant as markers of surface fresh water contamination by waste water; Sci Total Environ. 2014 484:19-26.

15. Chan CL Zalifah MK \& Norrakiah AS: Microbiological and physicochemical quality of drinking water The Malaysian J analyt Sci. 2007 11(2): 414-420.

16. Bhatt LR Lacoul HD Lekhak HD \& Jha PK: Physicochemical characteristics and phytoplankton of Taudaha lake, Kathamandu Poll Res. 1999 18(4): 353-358.

17. Ownby CR \& Kee DA: Chloride in lake. Eric Proc Cong Grat Lake. 1967: 382-389.

18. Chaudhary UK \& Ojha CSP: Environmental impact of the river Ganga at Varanasi Proc, Env Impact Assessment of Water Resources; Project Unive, Roorkee, 1985: 760-771.

19. Versari A, Parpinello GP \& Galassi S: Chemometric survey of Italian bottled mineral waters by means of their labeled physicochemical composition; J Food Compos Anal. 2002 15: 251-264.

20. Manandhar S \& Sharma S: Practical Approach to Microbiology, $3^{\text {rd }}$ edition; National Book Centre, Botahity, Kathmandu, 2003.

21. Goel PK: Water pollutions: causes, effects and control New Delhi-110002, India. H.S. Poplai; New Age International Limited,India, 1997.

22. Pandey VP, Chapagain SK \& Kazarna: Evaluation of ground water environment of Kathmandu Valley. Environ Earth Sci. 2010 60:1329-1342

23. Washington State Department of Health: Nitrates in Drinking Water. 1999. Retrieved from <http://www.doh.wa.gov/ ehp/dw/npp.htm>, $11 / 3 / 99$

24. Canter W: Nitrates in Groundwater; Lewis Publishers. 1997.

25. Subedi M \& Aryal M: Public perception about drinking jar water and its bacteriological analysis: Nepal Med Coll J. 2010 12(2):110-114

26. Rai SK, Ono K, Yanagida JI, Kurokawa M and Rai CK: Status of drinking water contamination in Mountain Region in Nepal. Nepal Med Coll J. 2009 11: 281-283.
27. Pant BR: Ground water in Kathamandu Valley of Nepal; Environ Monit Assess. 2010 178:147-185

28. Prasai T, Joshi DR, Lekhak B, \& Baral MP: Microbiological analysis of drinking water of Kathmandu Valley. Scientific World. 2007 5:112114.

29. Subedi M: Bacteriological quality of drinking water supplied in different schools of Kathmandu Valley; Nepalese Journal of Microbiology. 2011 2:50-55. 